\title{
Leadership Styles: Inertia and changes in the Czech Republic*
}

\author{
Werner Auer-Rizzi, Gerhard Reber ${ }^{* *}$
}

Social Darwinism suggests that in crisis situations leaders have to be replaced by better fitting leaders. An opposing school argues that leaders, based on their personality, are successful in all situations and therefore can master all situations including a crisis. A third view concludes that leaders can learn to overcome the path dependency of organizational structures. In this paper, the development and essentials of these approaches of leadership research are discussed and demonstrated in the case study of the Czech Republic after the Velvet Revolution. The test is based on the Vroom/Yetton model of leadership effectiveness. The results confirm that inertia and change can be explained based on the general contingency approach of leadership.

Gemäß der Theorie des Sozialdarwinismus werden in einer Krise Führungskräfte durch geeignetere ausgetauscht. Dagegen wird argumentiert, dass Führungskräfte auf Grund ihrer Persönlichkeit jegliche Situationen erfolgreich bewältigen können. Eine dritte Sichtweise schreibt Führungskräften Lernfähigkeit zu, mit der sie die Pfadabhängigkeit organisationaler Strukturen überwinden können. In diesem Aufsatz werden diese drei Sichtweisen der Führungsforschung diskutiert und am Fall der Tschechischen Republik nach der samtenen Revolution empirisch „getestet". Dieser „Test" basiert auf dem Vroom/Yetton Modell der Führungsforschung. Die Ergebnisse zeigen die Möglichkeit der Erklärung organisationaler Schwerkraft und Wandels mit kontingenztheoretischen Grundlagen der Führung.

Keywords: leadership behaviour; participation; Czech Republic; Vroom/Yetton model; cultural inertia; institutional change

\footnotetext{
Manuscript received: 05.05.2010, accepted: 10.05.2012 (2 revisions)

** Werner Auer-Rizi, Associate Professor, Department of Organization and Global Management Studies, Johannes Kepler University Linz. Main research areas: cross cultural/international aspects of management and leadership; group decision making, trust, organizational behavior. Corresponding address: AuerRizzi@jku.at

Gerhard Reber, Professor Emeritus, Johannes Kepler University Linz. Main research areas: organizational behavior, cross cultural aspects of management and leadership; global management education.
} 


\section{Major steps in the development of leadership theories}

According to Zaccaro (2007), the start of leadership research is to be found in trait theory which has led to two popular notions: "The first point defines leadership as a unique property of extraordinary individuals whose decisions are capable of sometimes radically changing the streams of history. [...] The second point grounds the unique attributes of such individuals in their inherited or genetic makeup. [...] The practical implication of this view, of course, is that leadership quality is immutable and, therefore, not amenable to developmental interventions" (Zaccaro 2007: 6).

In contrast to this heroic approach, Pfeffer, who conducted longitudinal studies of mayors, athletic coaches, and corporate leaders (Salancik/Pfeffer 1977), came to the conclusion that leadership is largely an illusion generated by peoples' need for heroes. "If one cannot observe differences when leaders change, then what does it matter who occupies the position or how they behave" (Pfeffer 1977: 59).

Contrary to both extreme positions - leaders move the world vs. leaders are irrelevant - the development of trait theories made important steps in analysing essentials of intrapersonal dispositions for effective leadership as a social phenomenon. Already in 1931, Moss came to the conclusion that cognitive abilities combined with social competence can create leadership effectiveness (Moss 1931). This theme can be seen as the core topic in all models in the development of leadership theories.

In the tradition of trait theories but putting an accent on intrapersonal dispositions, Sternberg (2007) for example, differentiates in his WICS-model (wisdom, intelligence, creativity) between ten creative attitudes, academic and practical intelligence, and wisdom as elements of leadership. Research on motivational prerequisites of leadership effectiveness also has a long tradition. Here the leading schools are based on the work of McClelland (1985), who concentrates on the achievement, power, affiliation and avoidance motives (McClelland et al. 1953; Atikinson/Feather 1966; Heckhausen 1980; McClelland/Winter 1969). In this tradition, McClelland/Boyatzis (1982) applied a "leadership motivation pattern" (moderate-to-high in power, lower in affiliation, and high in self-control or activity inhibition) to a case study with 237 managers with the result that this pattern "[...] was significantly associated with managerial success after 8 and 16 years for the non-technical managers" (McClelland/Boyatzis 1982: 737). For differentiating the motive pattern they applied the projective Thematic Apperception Test (TAT) in the version of Heyms et al. (1958) and assumed that the individual motive patterns are stable.

The development of behaviourism moved the research in leadership away from "introspection" and projective tests into the direction of "behaviour", which was investigated mainly by questionnaires - a tradition which still dominates today 
(Taras et al. 2009). In terms of content, we see the same two areas as Moss had mentioned: cognitive/goal oriented and social competencies in many forms and different terms. The classical form was developed in the Ohio/Michigan studies with the differentiation between "consideration" (concern and respect, welfare, appreciation and support for followers) and "initiating structure" (oriented towards goal attainment, establishment of well-defined patterns and channels of communication). The differentiation is based on the "Leader Behaviour Description Questionnaire (LBDQ)" by Hemphill and Coons (1957) resp. in a German version as "Vorgesetzen-Verhaltens-Beschreibung (FVVB)" by Fittkau and Fittkau-Garthe (1971). According to Fleishman (1998: 51), "consideration and initiating structure have proven to be among the most robust of leadership concepts." Judge et al. (2003) support this view in a meta-analysis against all criticism on various grounds.

In the discussion around the Ohio/Michigan studies quite similar concepts were developed, the closest being the version of Blake et al. (1962) with the managerial grid. This version includes a training concept which should lead managers to reach perfection in both dimensions (concern for "production" and "people"), symbolized in Blake and Mouton's (1978) terms as "9/9-managers". Bales (1966) differentiated between "person- and task oriented behaviours". Also the distinction between transformational and transactional leadership (Burns 1978; Bass 1985) is based on the task- and relationship orientation of leaders, including the concept of charisma. An interesting difference between Burns and Bass is that Bass did not see transactional and transformational as separate concepts. Bass argued - similar to the concept of the managerial grid that the best leaders are both transformational and transactional. House was also stunned by the development of the two dimensional concepts when developing two theories, the path-goal theory (House 1971; 1996), based on concepts of Evans (1970), and his attempt to renew the charisma concept (House 1977). Both theories are related to the concept of transformational leadership, whereby more attention is given to the attributes of the charismatic dimension, especially in respect of the importance of this style in the intercultural context of leader effectiveness. This research stream with the trademark "GLOBE Project" (House et al. 2004) also applies questionnaires in the behaviouristic tradition. As far as leadership styles are concerned, this project led to the conclusion, that the charismatic style is the most successful leader behaviour across all investigated cultures (Dorfman et al. 2004: 669-719). This is also confirmed by Den Hartog et al. (1999) in a more differentiated elaboration of the concept. Such a result has the implication that in the differentiation of the Ohio/Michigan studies "consideration" resp. "social competence" seems to have priority in all cultures. Such a dominating effect also seems to contradict the contingency approach, which, according to Evans and House, was accepted as a cornerstone of all modern leadership theories. 
The contingency approach was introduced parallel to the behavioural method as a step beyond the intrapersonal trait concept. The contingency concept is based on the development of a branch in social psychology, to which Levin (1935) paved the way with his slogan that behaviour (B) is a function of personality factors $(\mathrm{P})$ and the situation $(\mathrm{S})$ in which persons have to act. With the comma between person and situation in the middle of the function $B=f(P, S)$ he left the door open for investigations of the specific person-situation relationships. Obviously, leadership is of an inherent social nature, leadership theory therefore had to be opened for research within the approach of social psychology (Lewin et al. 1939).

Fiedler (1967) developed a complete concept, combining personality and situational factors. The essentials of this theory are:

(1) The effectiveness of a group is contingent upon the appropriateness of the leader's style to the specific situation in which he operates. Most people are effective leaders in some situations and ineffective in others.

(2) The type of leadership style that will be most effective depends upon the degree to which the group situation enables the leader to exert influence.

(3) [...] Since it is extremely difficult to change a man's personality and leadership style, but relatively easy to change his work situation, we will examine 'an organizational engineering' approach to leadership and management development. (Fiedler 1968: 362)

In his approach of bridging $\mathrm{P}$ with $\mathrm{S}$, Fiedler, in the tradition of the trait theories, invented a projective test (LPC - Least Preferred Co-worker), where the situational variables are: leader-member relations, task structure, and positional power. With respect to the person dimension, Fiedler - in contrast to McClelland, who investigated "power" in the tradition of the trait theory as "power motive" - moved into the "situational arena". Fiedler's concept was very imaginative and thus very influential for the discussion of the relationship of "P2 and "S". His operationalization of both sides (LPC-test and all situational variables) was, however, not supported by numerous tests and meta-analyses (Peters et al. 1985; McMahon 1972; Meyer 1982).

The (main) leadership theories comprise many important concepts and aspects (Reber 1996), but did not find a common basic model. Many voices have urged an investigation of the advanced trait with the contingency concepts (for example: Sternberg/Vroom 2002; Zaccaro et al. 2004; Zaccaro 2007), but accepted results could not be achieved yet. Nevertheless, we can draw the following conclusions:

(1) The contingency theories underline that the core of leadership is a situational challenge. The situation varies in degrees from being well-structured and monotonous to ill-structured with very dynamic changes. 
(2) The leadership challenge has to get acceptance by potential leaders. This asks for their motivational stimulation (Kark/van Dijk 2007), which can reach from a basic curiosity drive (Berlyne 1965; Fowler 1965) to the differentiations made by McClelland (1985), but also to the level of conscious decision making processes (Vroom/Yetton 1970) and the involvement of commitment (Festinger 1957) and ethical engagement.

(3) Also cognitive abilities are challenged. These abilities include a variety of technical, managerial, interpersonal, and group behavioural, intercultural etc. competencies.

(4) Leadership theories demonstrate the importance of the two clusters of competencies as prerequisites for effectiveness. The use of different names like "transactional", task-/"roduction-" oriented behaviour for "professional competencies" versus "transformational", "charismatic" behaviours as "social competencies" highlight different accents within the two categories, but are also based on a common, intuitively appealing understanding. The differentiation is especially important for the discussion of learning, training and managerial development.

(5) It is generally accepted that (organizational) leadership effectiveness is a function of a "fit" or "match" between situational and personality factors.

(6) The learning/training aspect for the creation of „fit" finds extremely diverse characterization in the tradition of leadership theories: From "inherited" and "genetic" to Fiedler's "organizational engineering approach", which leads in his concept - at least to a learning perspective that a leader should try to change the situation and not his personality in order to be effective.

(7) In general: Leadership theories provide a variety of important insights into the area of explaining involved variables, tests and hints for improving effectiveness. What is missing for "practical" applications are (a) models that can differentiate the relative potency of intrapersonal dispositions and situational factors for actual behaviour and (b) clarifications of effective training devices within both categories of professional and social competence for the creation of leadership effectiveness. Important for future research is the advice to investigate which personality factors are "close-to-" or "far-from-" action (Locke/Latham 1980: 6; Szabo et al. 2001), or as Zaccaro (2007: 13) calls it, "distant" or "proximal" to leadership situations.

In order to overcome these bottlenecks, it seems necessary to follow Simon's (1960) advice to reduce complexity to the most essential variables, which can be understood and applied.

\section{Learning and selection}

Obviously, Fiedler's judgement that the change of "personality" is difficult to manage by the person him/herself or with the help of others is a serious 
experience. This phenomenon becomes more elastic when we differentiate between "professional" and "social" competencies. There is no doubt that (a) individuals, based on curiosity, are eager to learn from childhood on, and (b) educational processes help to avoid that every learning progress is only achieved by trial and error. Learning by imitation (vicarious learning - Bandura 1986: 283-334) is based on the initiative of the learners to avoid errors. However, vicarious learning bears the inherent risk that the learner may select the wrong model, which, for example, can happen in an endeavour of expatriate managers trying to adjust to managerial behaviour in a new, culturally different environment (Auer-Rizzi 2007). Pedagogy developed effective devices for schools and companies to help to improve the learning process, especially in the wide area of professional competencies. In the area of social competencies, however, successful learning in the past may have the dysfunction of producing inertia (Argyris 1985). This inertia can be explained by the concurrence of two processes. First of all, it is based on very early learning processes in childhood. For example, differences in social behaviour between German and Turkish children, depending on the educational style of the parents, were already found at the age of two (Biedinger 2009). Moreover, learned behaviour will be transferred from the "conscious" level of knowledge to the „tacit" level (Polany 1976; Wagner/Sternberg 1985) in order to save room in human memory and cognitive processes for new situational challenges. The "treasure" of tacit knowledge gives individuals constancy in their behaviour and predictability for companies and co-workers, but also misjudgements for situational changes. To overcome this inertia often dramatic acts - described as "unfreezing - change refreezing" by Lewin (1958) - or maybe time consuming self-learning processes are appropriate training processes. For the unfreezing process short-term events can be effective. Personal/social disasters, confrontations with different cultures, or providing "consciousness raising experiences" (Mirvis 2008) can be effective, but may have unexpected dysfunctional outcomes in the process of "change" and "refreezing". Well-controlled learning requires competent learning processes and time for reflection and contemplation.

Selection by forces of the "situation" is a realistic and practical alternative strategy to establish or re-establish the fit between personal abilities and situational requirements. Readjustments are especially visible in political and economic crisis situations. New leaders are a prerequisite for bringing about political revolutions, but may not be able to be successful to sustain the influence of the revolution as in the cases of the re-establishment of democracy in the European countries after the fall of the Iron Curtain. Reactions of the economy in the current financial crisis seem to follow the selection trend. For example, Seidlitz (2010: 18) reports that recently, in prominent German companies, a new generation of top managers were appointed for their managing boards with a different education and experience than their predecessors. He refers to firms like Beyer, Thyssen Krupp, BASF, Siemens, Metro, where CEOs 
with more or less the same characteristics were appointed. Dominant are external managers with an education at the doctoral level in business administration and/or MBAs. "A study by Booz Allen Hamilton came to the conclusion that in a comparison of the years $1995-2004$ the number of the replacements of CEOs increased by 300\%" (Seidlitz 2010: 18).

Such a process finds its theoretical underpinning in approaches of Social Darwinism like the population ecology theory (Hannan/Freeman 1977; Singh 1990), the path dependency theory (Ackermann 2001; Schreyögg/Sydow 2011) or the quantum view (Miller/Friesen 1984). For example, Miller and Friesen (1980) published an in-depth longitudinal study of 35 North American firms in a total of 135 transitional periods based on three sources (published histories in the form of books, lengthy series of cases, at least twenty years of continuous history, questionnaires that surveyed top executives about the events, and for each case four professional evaluators). Miller and Friesen (1980) found out that in all six successful archetypes of organizational transition the top executives were replaced. Nevertheless, Miller and Friesen came to the conclusion "[...] that it is wrong for researchers to look at organizations from a purely deterministic 'organization-adjusting-to-the-environment' point of view [...] while it is certainly true that some of the transitions portray environment as an incentive for changes in organization structure, strategy, and decision making style, it is equally true that past strategic choices and modes of behaviour influence the nature of the environment, that strategies influence structure (Chandler 1962), and that structure constrains strategic choice (Hedberg Nystrom, and Starbuck 1976)" (Miller/Friesen 1980: 151). A similar approach which questions a purely deterministic position and which regards managerial learning as an essential force for change of institutions and economic performance (North 1990) is the PNO (Policies, Norms, and Organizations) framework of the economist and Nobel Prize-winner Douglas North.

"Institutions are the rules of the game in a society or, more formally, are the humanly devised constraints that shape human interaction. In consequence they structure incentives in human exchange, whether political, social, or economic. Institutional change shapes the way societies evolve through time and hence is the key to understanding historic change" (North 1990: 3). North includes as institutions "formal" and "informal" elements: Formal are constitutions, laws, and contracts; informal are social norms and beliefs, conventions and codes of conduct.

Organizations include political bodies (political parties, the Senate, a city council, a regulatory agency), economic bodies (firms, trade unions, family farms, cooperatives), social bodies (churches, clubs, athletic associations) and educational bodies (schools, universities, vocational training centres). They are groups of individuals bound by some common purpose to achieve objectives. Modelling organizations is analysing governance structures, skills, and how 
learning by doing will determine the organization's success over time. Both, what organizations come into existence and how they evolve are fundamentally influenced by the institutional framework. In turn they influence how the institutional framework evolves. (North 1990: 5).

Individual "[1]earning [...] is a cumulative process of cultural conditioning in which the experiences of each generation are filtered through the existing belief system and result in its incremental modification." (North 1996: 3).

The definitions demonstrate a conviction of "inertia" within the different cultures and the path dependency in the development of historic cultures. But North differentiates the stability between the elements of his framework:

[T] he fundamental source of change is learning by entrepreneurs of organizations. [...] Change is typically incremental, reflecting ongoing ubiquitous evolving perceptions of the entrepreneurs of organizations in the context of an institutional matrix that is characterized by network externalities, complementarities and economies of scope among the existing organizations. Moreover since the organizations owe their existence to the institutional matrix, they will be an ongoing interest group to assure the perpetuation of that institutional structure- thus assuring path dependence. Revolutions do occur, however, when organizations with different interests emerge (typically as a result of dissatisfaction with the performance of existing organizations) and the fundamental conflict between organizations over institutional change cannot be mediated within the existing institutional framework. Path dependence means that history matters; that the choices we make today and tomorrow are constrained by the past evolution of the belief systems and institutions of the society. (North 1996: 10f).

The velvet revolution in the Czechoslovakia provides a historically interesting development. It is obvious that political „entrepreneurs“, who were dissatisfied with the performance of existing institutions, created a far-reaching institutional change with this revolution. The question remains whether this change was also able to overcome the path dependency in the economic sector of this society. Did organizations provide enough social support, so that individual "entrepreneurs" were able to become effective as leaders for change?

The Velvet Revolution in Czechoslovakia created the opportunity for a complete reconstruction of its society and economy. The economy before the revolution with central planning and inclusion in the COMECON was transferred into a liberal system with private property by the application of a voucher technique (Kost 1994) and the opening of a competitive, internationally open free market structure. The role of the communist party system was replaced by a democratic, pluralistic system with a new constitution. Within this system even a separation of the country in two completely separate countries - the Czech Republic and 
the Slovak Republic - could be achieved in a democratic process and in the years both countries joined the European Union.

Not all changes functioned in the expected ideal quality, but the transfer overall provided and effective change in the governmental structure (Lavigne 1995; Clark/Soulsby 1999; Maly 2000). The question remains and provides a fascinating "construction site" for studies to find out whether all these essential changes also provided momentum to overcome the path dependence on the individual level and especially for our research question of professional leadership behaviour within privatized firms. Our empirical research is concentrated on the situation within the Czech Republic.

\section{Hypotheses}

The Social Darwinist theories found empirical support in the area of leadership. These selection approaches contradict also positive empirical results based on theories that "learning can be successfully provided" (Reber 1995; Reber et al. 1997; Vroom 2000; 2003). According to Cronbach (1957), the conflict between both schools was discussed in the development of "scientific" psychology:

The theory of evolution inspired antagonistic movement in social thought. Darwin and Herbert Spencer were real determinists. The survival of the fittest, as a law of Nature, guaranteed man's superiority and the ultimate triumph of natural aristocrats among men [...] The experimental scientist inherits an interpretation of evolution associated with the names of Ward, James, and Dewey. For them, man's progress rests on his intelligence; the great struggle is a struggle against environment, not against competitors. [...] This spirit [...] bred today's experimental social science which accepts no institution and no traditions as sacred. The individual is seen as inherently self-directing and creative. (Cronbach 1957: 678f)

Such an "individualistic" approach against Social Darwinism is relativized by North's (1990, 92ff) analysis that individuals need social help for learning to succeed. The dramatic changes in Central Europe and our leadership studies in the Czech Republic give us a chance to report about results regarding this old conflict between selection and learning with the forces on leadership in industry.

This leads us to the following hypotheses: In the Czech Republic, after the Velvet Revolution

(1) The leadership style did not change,

(2) Inertia continued in both categories of leadership effectiveness: professional (2a) and social competence (2b), and

(3) Social/organizational support will lead to learning and change.

The empirical evaluation of these hypotheses will be based on the Vroom/Yetton model of leadership (Vroom/Yetton 1973). 


\section{The Vroom/Yetton model of leadership effectiveness}

The Vroom/Yetton model is anchored in the framework of social psychology and its accent on the influence of the social situation for the behaviour of individuals. But in contrast to the radical Darwinist approach, the model is developed as the basis for successful training devices. The central idea of such learning to be effective as leaders is to enable individuals to become flexible with their leadership styles provided that they improve their ability to diagnose the differences between leadership situations. The model also follows the behavioural approach, but does not use questionnaires for collecting data in response to the tacit knowledge of leadership behaviour. Instead of questionnaires, a set of 30 cases is used, where the responses are "close to behaviour" (Locke/Latham 1990; Szabo et al. 2001). The model tries to follow the concept of "bounded rationality" (Simon 1960) to reduce complexity in the dimension of the "magical number seven plus or minus two" (Miller 1956; Baddley 1994). This approach leads to seven leadership styles, seven questions to diagnose the situation, and seven normative rules for improving leadership effectiveness.

Leadership styles: The differentiation of five leadership styles is based on the studies of participation in the Human-Relations (Roethlisberger/Dickson 1940) and the Lewin (Marrow 1977) schools. In this conduct, different scales of participation were developed (Lewin et al. 1939; Tannenbaum/Schmidt 1958; Likert 1961). In the discussion about the quality of participation and the limits, Vroom came to the conclusion that the effectiveness of participation varies from situation to situation (Vroom 1970). Therefore, the positive effects of participation are seen as relevant to leadership effectiveness, but only within the limits of situational opportunities. Based on the existing scales, the model differentiates between five styles with an increasing degree of participation from "AI to GII" (see Appendix 1).

Diagnostic questions: The diagnostic questions (see Appendix 2) are created for the leader to help him/her analyse the situation in which the strategies are to be applied. The seven questions are based on Maier's (1955) differentiation between quality and acceptance requirement. Questions A, B, and C relate to the quality dimension, and D, E, F, G to the acceptance level.

Decision rules: Each of the seven decision rules (see Appendix 3) excludes certain strategies for particular situations. The application of the seven rules leads to one or more strategies (feasible set) appropriate to fulfil the requirements of the organizational goals in the specific situation. When the feasible set contains more than one strategy, the model adds two additional selection criteria, time and subordinate development. Model A is targeted to time saving among the feasible strategies; Model B replaces the goal of time efficiency with the goal of subordinate development and recommends the most 
participative strategy among the feasible alternatives. The more the behaviour of the leader is congruent with the rules, the more effectively the organization's objectives can be achieved. Several validation studies confirm this assumption (Böhnisch 1991: 34f).

\section{Validation of the model}

The empirical validation of the Vroom/Yetton model was challenged in two aspects. One was the validity of the case set, the other - more comprehensive the validation of the whole construct. The validation of the case set had to prove that the individual reactions of managers to the case descriptions would be congruent with their real behaviour on the job. Two different studies in two cultures confirm this hypothesis (Jago/Vroom 1978; Böhnisch et al. 1988). The whole concept proved its validity in several studies (Vroom/Jago 1978; Zimmer 1978; Field 1979; 1982; Miner 1984; Miller/Monge 1986; Tjosvold et al. 1986; for a summary of these studies see: Reber, 1995; Vroom/Jago 2007).

All the validity studies confirm the robustness of the complexity reduction of the model. For example, Jago (1978) concentrates an empirical investigation in detail on all the essential parts of the model - diagnostic questions, normative rules, set of 30 cases - and came to the following conclusion:

Vroom and Jago (1974) argued that it makes more sense to talk about autocratic and participative situations rather than autocratic and participative managers. The results of the present investigation suggest that it makes even more sense to talk about autocratic and participative decision rules employed in choosing a behaviour for a situation. Some of these rules seem to be common across managers (as reflected in within-person effects); some are apparently unique to individual managers (as reflected in between-person interaction effects. (Jago 1978: 492).

Jago also found in his study that in the core of the model, i.e. in the critical area of participation, conflicts in special situations contradict cognitive rules:

Under conditions where participation might be expected to increase subordinate acceptance of a decision, respondents exhibit less participation if conflict is likely than if it is unlikely. Under conditions where subordinate acceptance is irrelevant, respondents exhibit more participativeness if conflict is likely than if it is unlikely. (Jago 1978: 492)

This finding led Jago to the subsequent conclusion:

In their validation study, Vroom and Jago (1978) report substantial evidence in support of all of the Vroom/Yetton principles except the one dealing with subordinate conflict. (Jago 1978: 492f.)

These insights together with others in the area of the bifurcations, which led to the famous "decision tree" of the model, led Vroom and Jago (1988) to a more 
sophisticated revised model under the name "The New Leadership". But the validation studies of this new model (Brown/Finstuen 1993; Field/Andrews 1998) found only incremental improvements in comparison with the original model (Vroom/Jago 2007: 21) for the price that the new model substantially increased the difficulties for managers in teaching situations. In principle, however, Jago's findings in the reaction of managers when conflicts are inherent in situations where participation is necessary according to the normative rules, led him to the conclusion, "Indeed, affective reactions to situations may interfere with cognitive processing in real managerial decisions perceived to be highly consequential for the decision maker (Janis/Mann 1977)" (Jago 1978: 495). Maybe McClelland and Boyatzis' (1982) inclusion of "self-control" or "activity inhibition" in the personalities of the involved people might be a good prevention against "affective" dysfunctional reactions in conflict situations. In principle, this underlies the general understanding between modern trait theorists and situational specialists to combine both perspectives in future leadership models (Vroom/Sternberg 2002).

\section{Data collection}

The data were collected in two settings: one was an executive program of the Prague International Business School (PIBS) at the University of Economics in Prague and in Olomouc. This interaction provided the reactions of 1,174 middle managers from very diverse organizations in different industries including, including the health care system, for a longitudinal study for the period from 1991 to 2011.

The second setting was within Skoda, the company with a very specific organisational structure. After the takeover by Volkswagen, a special matrixform called "Tandem" was introduced in order to facilitate the integration process. A Czech and a German (expatriate) manager were appointed to the most important hierarchical positions from the management board down and each person in the Tandem had the same formal power. Only upon agreement by each partner could a decision be considered as rendered. As the company takeover was completed in a very short period (Dorow/Varga von Kibed 1997; 2006), the managers of both nationalities were ill prepared for tasks and duties of this nature. The Tandem's challenging mission was accompanied by numerous conflicts, as there was not much trust and acceptance due to the negative historical prejudices concerning relations between Czechs and Germans as well as a long tradition of pride in both companies. Skoda, in particular, was and is a company with a long history and a high reputation in the Czech Republic. The Tandem model was discontinued as soon as the integration process had become successful and the partners in the model had learned to cooperate. Despite the higher labour cost - especially in the integration phase in comparison to any other VW plant worldwide, the new generation of Skoda 
vehicles proved to be very profitable and the Skoda subsidiary became a wellrespected unit within the VW Corporation.

The Tandem model provided a specific situation, where "social support" for learning was included in the form of "forced compliance", as stated in the framework of cognitive dissonance theory (Festinger 1957; Festinger/Carlsmith 1958; Brehm 1966). Our sample of Skoda managers consisted only of 47 Czech managers after the majority of German managers had already left the Skoda organization in the Czech Republic.

In both settings, the managers volunteered to participate in the project. The Vroom/Yetton Case-Set Nr. 5 was sent to them by E-mail, with the request to read the cases and to indicate for each one of the 30 cases which decisionmaking strategy they would choose in that particular case. Their reactions were analysed and a printed feedback-set was prepared. The group met the researchers in a feedback session during an executive program, or in the Skoda factory, where the Vroom/Yetton concept and the feedback sheets were explained at length (6-8 hours).

A complete training programme, with normally two meetings of two and a half days each - within a time frame of four to eight months between the two meetings - was not provided. The results of complete training sessions demonstrate positive learning effects (Reber 1988; Böhnisch 1991; Reber/Maczynski 2001; Vroom 2003). Feedback and the training programme are provided on a purely cognitive level, where the reactions of the participants are compared with the normative prescriptions of the Vroom/Yetton model. The deviations between the reactions of the managers and the "effective" recommendations of the model may lead to an "unfreezing" effect for the participant, which may/should cause learning intentions that are then supported by the next steps in a training programme.

The data were partially used in intercultural studies (Reber et al. 1991; Szabo 1997; Reber et al. 2000; Reber et al. 2002; Reber/Auer-Rizzi 2003; Reber et al. 2004;).

\section{Empirical results}

We divided the data into 5-year periods (1991-1995, 1996-2000, 2001-2005, and 2006-2011), with the exception of the last period, which has 6 years. We analysed the data employing one-way ANOVAs with the five-year blocks as independent variable (columns in Table 1) and various separate measures of the Vroom/Yetton model as dependent variables (lines in Table 1). The results are summarized in Table 1. We report the means of each dependent variable for each period and in the last column the F-value and significance of the one-way ANOVA analysis for each dependent variable. 
Table 1: Czech Managers 1991-2011

\begin{tabular}{|c|c|c|c|c|c|}
\hline Period & $91-95$ & $96-00$ & $01-05$ & $06-11$ & OneWay \\
\hline Number of Participants $(\mathrm{N})$ & 370 & 188 & 328 & 288 & 1174 \\
\hline \multicolumn{6}{|l|}{ Use of Strategies in \% } \\
\hline Al - Autocratic & 26,62 & 24,01 & 25,39 & 26,42 & n.s. \\
\hline All - Autocratic & 20,32 & 20,92 & 21,18 & 21,01 & n.s. \\
\hline $\mathrm{Cl}$ - Consultative & 16,10 & 17,11 & 15,44 & 15,69 & n.s. \\
\hline Cll - Consultative & 22,67 & 23,58 & 24,05 & 22,97 & n.s. \\
\hline GII - Group & 14,29 & 14,38 & 13,94 & 13,90 & n.s. \\
\hline Mean Level of Participation (MLP) & 4,25 & 4,39 & 4,30 & 4,22 & n.s. \\
\hline Intrapersonal Standard Deviation & 3,73 & 3,67 & 3,74 & 3,71 & n.s. \\
\hline \multicolumn{6}{|l|}{ Agreement (in \%) with } \\
\hline Feasible Set & 67,00 & 65,69 & 65,92 & 65,54 & n.s. \\
\hline Model A - Time Efficiency & 37,86 & 34,31 & 35,54 & 35,13 & $6,10^{\star * \star}$ \\
\hline Model B - Development Orientation & 19,99 & 20,71 & 20,56 & 20,49 & n.s. \\
\hline \multicolumn{6}{|l|}{ Rule Violations in \% } \\
\hline R 1 - Information Rule & 12,57 & 12,01 & 12,65 & 13,48 & n.s. \\
\hline R 2 - Goal Congruence Rule & 09,37 & 09,40 & 07,90 & 08,48 & n.s. \\
\hline R 3 - Unstructured Problem Rule & 46,89 & 48,40 & 45,02 & 46,87 & n.s. \\
\hline R 4 - Acceptance Rule & 28,92 & 28,88 & 31,55 & 33,13 & $4,77^{\star \star}$ \\
\hline R 5 - Conflict Rule & 50,00 & 51,91 & 52,87 & 53,82 & n.s. \\
\hline R 6 - Fairness Rule & 57,16 & 62,50 & 60,82 & 62,50 & n.s. \\
\hline R 7 - Acceptance Priority Rule & 69,73 & 71,41 & 72,56 & 73,78 & n.s. \\
\hline Sum. Quality Rules (R1-3) & 18,15 & 18,24 & 17,23 & 18,16 & n.s. \\
\hline Sum. Acceptance Rules (R4-7) & 44,40 & 45,67 & 47,23 & 48,59 & $4,75^{\star \star}$ \\
\hline$p<0,05 \quad{ }^{* *}=p<0,01 \quad{ }^{* \star *} p$ & & & & & \\
\hline
\end{tabular}

We can see in Table 1 that for almost all dependent variables the results of the analysis of variance did not show any significant differences between the different periods. For assessing changes in leadership style, we had a look at the "Use of Strategies" for the different periods. The results of the analysis of variance did not show any significant differences for the preference of the different strategies between the periods. Also the "Mean Level of Participation" as an aggregate measure of leadership style preference did not change over time. We can conclude that Hypothesis 1 is confirmed for the period between 1991 and 2011 in the "individualistic" setting, where the participants in the executive programs did not have the integration or support of their organizational business environment. Members of the class may be "entrepreneurs" in the definition of Douglas North (1990), but could not find the support of their social environment. 
Having a look at the violation rates of the normative rules of the Vroom/Yetton model, we can see that social competence (Acceptance Rules (rules 4-7)) is "underdeveloped" in comparison with professional competence (Quality Rules (rules 1-3)). The one-way analysis of variance also does not show any significant differences between the different periods for the different variables with the exception of an increasing violation rate of the "Summary of Acceptance Rules (Rules 4-7)", which is mostly due to an increased violation of Rule 4 (Acceptance Rule). That means that in the last two periods, Czech managers have been slightly more enforcing their decisions in case their subordinates did not agree with them. However, this means "inertia" even "developed more weight". We can conclude, that Hypothesis 2a and 2b were also confirmed. The stability continued in both main categories in the normative section of the Vroom/Yetton model.

Figure 1: Mean level of participation of Skoda Managers in comparison to other Czech and German Managers

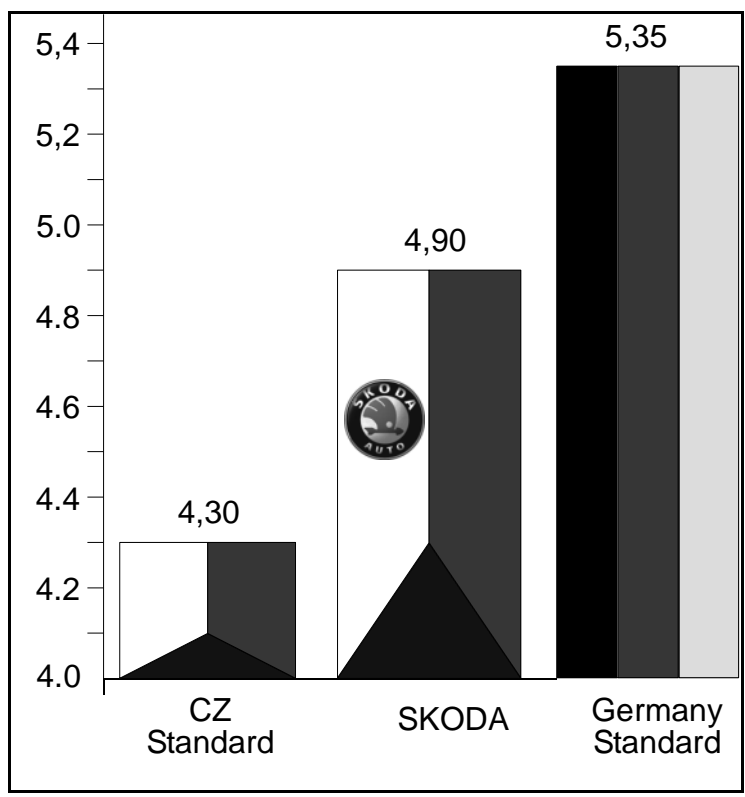

Figure 1 shows the Mean Level of Participation of Skoda managers compared to all other Czech managers in our database and to German managers. The results of a one-way analysis of variance show a significant difference between the Skoda managers and the other Czech managers $(\mathrm{F}=15,70 ; \mathrm{p}<0,001)$. Accordingly, in Figure 2 the lower violation rate of quality rules by Skoda managers compared to the other Czech managers is also statistically significant $(\mathrm{F}=4,50 ; \mathrm{p}<0,05)$. Although the lower violation rate of acceptance rules by Skoda managers compared to other Czech managers points in the right direction in terms of leadership effectiveness, it is not statistically significant $(\mathrm{F}=1,527$; n.s.). We conclude, that Hypothesis 3 is also confirmed. In the situation of the autocratically introduced matrix organization the individuals had no chance to avoid conflict situations. Their only chance to survive in the company was to cope with the situation as equals and to find among themselves a way of mutual 
conflict resolutions in order to be effective in the reorganized company ("forced compliance situation" - Festinger/Carlsmith 1959). Such a challenge was not easy to cope with. We can assume that an "unfreezing - change - refreezing" of their behavioural styles made it possible that the members of both cultures did not assimilate one of the two cultures, but found a new, acceptable way of interaction and increased their leadership effectiveness without any (external) training in the direction of the Vroom/Yetton model. The decrease of rule violations in forced compliance situations is a driving force for increases in leadership effectiveness.

Figure 2: Violation of quality rules by Skoda Managers in comparison to other Czech and German Managers

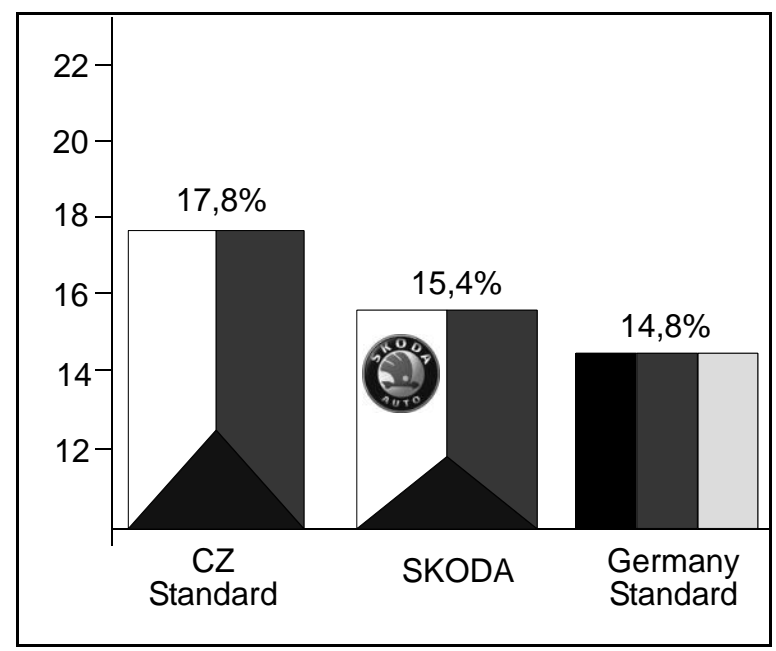

Figure 3: Violation of acceptance rules by Skoda Managers in comparison to other Czech and German Managers

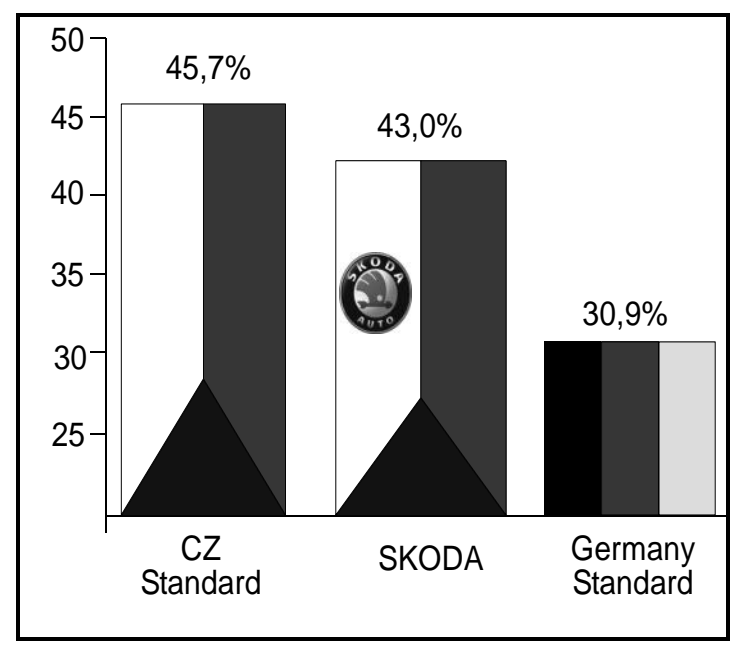

Nevertheless, the overall reduction of rule violations in the Skoda setting could not reduce the discrepancies between professional competencies (rules $1-3$ ) and social competencies (rules $4-7$ ). Approximately the double amount of violations in the area of social competencies was found in all countries/cultures 
where we were able to collect data. As predicted for this area, the tacit knowledge built into the personality from an early age and enforced during the social learning process seems to be the "bottleneck" of leadership effectiveness. Formal learning processes in schools and universities are concentrated on the development of professional competencies, but the development of social competencies is neglected.

The investigation of control variables shows that neither age group differences nor gender differences indicate any statistically significant results.

\section{Discussion}

The theories of North (1990) in his PNO model found a complete validation. Many different schools in the area of management have studied the complicated problem of inertia and change. They very often did not find an integration of elements of inertia and learning. North, who studied the development of economies, combines both, a) inertia in institutions and social/cultural norms, and b) change introduced by individual leaders. The key seems to be that those "entrepreneurs" of organizations, who initiate change, find sufficient social/structural support from their organizations over time. Studies, which were started by the two alternative schools, inertia versus learning and change, led sometimes to empirical findings that validated the opposite point of view. For example, Dobusch (2008), who started within a research program dedicated to the explanation of path dependency of organizations (Ackermann 2001), showed that municipal public organizations could overcome resistance against the introduction of a computer program by making essential changes in the organizational structure and job adaptions. By comparing two similar banks, Reber (1995) found opposite outcomes after leadership trainings based on the Vroom/Yetton model. In both organizations top management welcomed and supported the training program, but in one bank the top manager did not attend the training and did not change his highly autocratic behaviour. In this bank, the training was not successful in comparison to the other bank, where a completely new leadership style was created.

The contingency theories of leadership are another step towards the integration of both schools. After some essential changes, the leaders of the change process lose their influence; they cannot adapt to the new, "normal" times, and lose the support of their social environment, which is busy digesting the newly established situation. Miller and Friesen (1984: 25) provide an example of such a development with the crisis of Volkswagen, when the successful "Beetle"program lost its attractiveness. The leader of the Audi subsidiary which, at the time was small and neglected, but had a renewed product line, was appointed to the position of CEO of the Volkswagen group in a "quantum approach." In this function he introduced drastic changes and thus turned around the whole 
company. However, very soon after profits were secured, he lost his leadership position.

The findings in our study indicating that gender differences had no impact on the inertia of behaviour are in contrast to results found by Rost and Osterloh (2010). They made empirical studies in crisis situations in the Swiss banking industry. Their results demonstrated that female executives were able to diagnose and react to such situations with a much higher degree of professional competence than their male colleagues. Nevertheless, this performance did not result for women in obtaining higher positions in these banks. Maybe the female managers did not get enough social support from the dominant male environment in the governance structure of these organizations.

The important role of social competencies is obviously not a new aspect in the development of leadership theories. Especially, the focus on transactional and charismatic aspects of leader behaviour confirms this importance. The Vroom/Yetton model in its endeavour to focus on essentials of successful participation brings hands on attention to social conflicts that have to be mastered in order to reach leadership effectiveness. This is done in such a way that all acceptance rules (rules 4, 5, 6, and 7) are centred on different conflict parties and on the case methodology, which brings these conflict constellations into the open. The acceptance rules are targeted to three conflict constellations: (1) disagreements between the leader and the subordinates, (2) self-interests of the subordinates versus the goals of the organization, and (3) conflicts within the group of subordinates. As mentioned above, Jago (1978) found in his investigations that leaders have special problems to apply different rules for participation when intense group conflicts are to be expected. Such a finding is consistent with two beliefs, namely (1) "[...] that group participation exacerbates rather than reduces conflict thereby jeopardizing needed commitment [...] [2] The second effect would be consistent with the belief that the full expression of such conflict may, at the same time, serve decision quality thus making conflict useful under conditions where subordinate acceptance is not threatened" (Jago 1978: 492).

To obtain a deeper understanding of such delicate forms of conflict, or more or less the abilities of conflict resolution, depends on information earned through appropriate data collection. Here validated case sets demonstrate advantages over the collection of data in questionnaires. However, the latter form of data collection dominates the field of leadership research. In the comprehensive GLOBE-study under the direction of House (2004) for example, subordinates of middle managers were asked to characterize effective leadership. In all cultures the "charismatic" style got the highest approval. The questionnaire was based on very positive attitudes (visionary, inspirational, self-sacrifice, integrity, decisive, performance oriented). Conflicts and conflict resolution were not mentioned at 
all. It will be important for future research to apply triangular methods and longitudinal studies to gain further insights.

\section{References}

Ackermann, R. (2001): Pfadabhängigkeit, Institutionen und Regelformen, Tübingen: Mohr Siebeck.

Argyris, C. (1985): Strategy, change and defensive routines, Boston: Pitman.

Atkinson, J.W./Feather, N.T. (1966): A theory of achievement motivation, New York: Wiley \& Sons.

Auer-Rizzi, W. (2007): Führungsverhalten: Anpassung und Lernen im interkulturellen Kontext, in: Auer-Rizzi, W./Blazejewski, S./Dorow, W./Reber, G. (eds.): Unternehmenskulturen in globaler Interaktion: Analysen, Erfahrungen, Lösungsansätze, Wiesbaden: Gabler, 93-114.

Baddeley, A. (1994): The magical number seven: Still magic after all these years, in: Psychological Review, 101, 2, 353-356.

Bales, R.F. (1966): Task roles and social roles in problem solving groups, in: Biddle, B.J./Thomas, E.J. (eds.): Role theory, New York: Wiley, 254-262.

Bandura, A. (1986): Social foundations of thought and action, Englewood Cliffs: Prentice Hall.

Bass, B.M. (1985): Leadership and performance beyond expectations, New York: Free Press.

Berlyne, D.E. (1965): Structure and direction in thinking, New York: Wiley.

Biedinger, N. (2009): Der Einfluß von elterlichen Investitionen auf die Entwicklung deutscher und türkischer Kinder, in: Berliner Journal für Soziologie, 19, 2, 268-294.

Blake, R.R./Mouton, J.S. (1978): The new managerial grid, Houston: Gulf.

Böhnisch, W. (1991): Führung und Führungskräftetraining nach dem Vroom/Yetton-Modell, Stuttgart: Schäffer-Poeschel.

Böhnisch, W./Jago, A.G./Reber, G. (1987): Zur interkulturellen Validität des Vroom/Yetton Modells, in: Die Betriebswirtschaft, 47, 1, 85-93.

Böhnisch, W./Ragan, J.W./Reber, G./Jago, A.G. (1988): Predicting Austrian leader behavior from a measure of behavioral intent: A cross-cultural replication, in: Dlugos, G./Dorow, W./Weiermair, K. (eds.): Management under differing labour market and employment systems, Berlin, New York: De Gruyter, 313-322.

Brehm, J.W. (1966): A theory of psychological reactance, New York: Academic Press.

Brown, F.W./Finstuen, K. (1993): The use of participation in decision making: A consideration of the Vroom-Yetton and Vroom-Jago models, in: Journal of Behavioral Decision Making, 6, 3, 207-219.

Burns, J.M. (1978): Leadership, New York: Harper and Row.

Chan, K.-Y./Drasgow, F. (2001): Toward a theory of individual differences and leadership: Understanding the motivation to lead, in: Journal of Applied Psychology, 86, 3, 481 498. 
Chandler, A.D. (1962): Strategy and structure: Chapters in the history of industrial enterprise, Cambridge, MA: MIT Press.

Clark, E./Soulsby, A. (1999): Organizational Change in Post-Communist Europe: Management and Transformation in the Czech Republic, London: Routledge

Cronbach, L.J. (1957): The two disciplines of scientific psychology, in: American Psychologist, 12, 11, 671-684.

Den Hartog, D.N./House, R.J./Hanges, P.J./Ruiz-Quintanilla, S.A./Dorfman, P.W./Brodbeck, F./Reber, G./Szabo, E./Weibler, J./Wunderer, R./co-authors (1999): Culture specific and cross culturally generalizable implicit leadership theories: Are attributes of charismatic/transformational leadership universally endorsed?, in: Leadership Quarterly, 10, 2, 219-256.

Dobusch, L. (2008): Windows versus Linux: Markt - Organisation - Pfad, Wiesbaden: VS Verlag für Sozialwissenschaften.

Dorow, W./Varga von Kibed, G. (1997): Market entry in Eastern Europe as a challenge for expatriates - Case study: The Volkswagen-Skoda joint venture in the Czech Republic, in: Wagner, D. (ed.): Bewältigung des ökonomischen Wandels; Entwicklung der Transformationsforschung in Ost und West, München: Hampp, 208-217.

Dorow, W./Varga von Kibed, G. (2006): Transformation von Unternehmenskulturen im Spannungsfeld west-europäischer Wertedifferenzen: Zwei Fallbeispiele für Lösungsansätze deutscher Konzerngesellschaften, in: Beichelt, T./Choluj, B./Rowe, G.C./Wagner, H.-J./Lange, T. (eds.): Europa-Studien: Eine Einführung, Wiesbaden: VS Verlag für Sozialwissenschaften, 415-432.

Evans, M.G. (1970): The effects of supervisory behavior on the path-goal relationship, in: Organizational Behavior and Human Performance, 5, 3, 277-298.

Festinger, L. (1957): Theory of cognitive dissonance, Stanford, CA: Stanford University Press.

Festinger, L./Carlsmith, J.M. (1958): Cognitive consequences of forced compliance, in: Journal of Abnormal and Social Psychology, 58, 2, 203-210.

Fiedler, F.E. (1967): A theory of leadership effectiveness, New York: McGraw-Hill.

Fiedler, F.E. (1968): Personality and situational determinants of leadership effectiveness, in: Cartwright, D./Zander, A. (eds.): Group Dynamics, 3 ed., New York: Harper and Row, 362-380.

Fiedler, F.E./Chembers, M.M. (1984): Improving leadership effectiveness. 2 ed., New York: Wiley.

Field, R.H.G. (1979): A critique of the Vroom-Yetton contingency model of leadership behavior, in: Academy of Management Review, 4, 2, 249-257.

Field, R.H.G. (1982): A test of the Vroom/Yetton normative model of leadership, in: Journal of Applied Psychology, 67, 5, 523-532.

Field, R.H.G./Andrews J.P. (1998): Testing the incremental validity of the Vroom-Jago versus Vroom-Yetton models of participation in decision making, in: Journal of Behavioral Decision Making, 11, 4, 251-261.

Fittkau-Garthe, H./Fittkau, B. (1971): Fragebogen zur Vorgesetzten-Verhalten-Bewertung (FVVB), Göttingen: Hofgrefe. 
Fleischman, E.A. (1995): Consideration and structure: Another look at their role in leadership research, in: Dansereau, F./Yammarino, F.J. (eds.): Leadership: the multiple-level approaches, Stamford, CT: JAI Press, 51-60.

Fowler, H. (1965): Curiosity and exploratory behavior, London: Macmillan.

Hannan, M.T./Freeman, J. (1977): The population ecology of organizations, in: American Journal of Sociology, 82, 5, 929-964.

Heckhausen, H. (1980): Motivation und Handeln, Berlin: Springer.

Hedberg, B.L.T./Nystrom, P.C./Starbuck, W.H. (1976): Camping on seesaws: Prescriptions for a self-designing organization, in: Administrative Science Quarterly, 21, 1, 41-65.

Hemphill, J.K./Coons, A.E. (1957): Development of the leader behavior description questionnaire, in: Stogdill, R.M./Coons, A.E. (eds.): Leader Behavior: Its description and measurement, Columbus: Bureau for Business Research, Ohio State University, 638 .

Heyns, R.W./Veroff, J./Atkinson, J.W. (1958): A scoring manual for the affiliation motive, in: Atkinson, J.W. (ed.): Motives in fantasy, action and society, New York: Van Nostrand, 205-218.

Hirschman, A.O. (1970): Exit, voice, and loyalty: Responses to decline in firms, organizations, and states, Cambridge, MA: Harvard University Press.

Hofstede, G./McCrae, R.R. (2004): Personality and culture revisited: Linking traits and dimensions of culture, in: Cross Cultural Research, 38, 1, 52-88.

House, R.J. (1971): A path-goal theory of leader effectiveness, in: Administrative Science Quarterly, 16, 3, 321-338.

House, R.J. (1977): A 1976 theory of charismatic leadership, in: Hunt, J.G./Larson, L.L. (eds.): Leadership: the cutting edge, Carbondale: Southern Illinois University Press, 189-207.

House, R.J. (1991): Leadership: A new synthesis, Newbury Park: Sage.

House, R.J. (1996): Path-goal theory of leadership: Lessons, legacy and a reformulated theory, in: Leadership Quarterly, 7, 3, 323-352.

House, R.J./Hanges, P.J./Javidan, M./Dorfman, P.W./Gupta, V. (Eds.) (2004): Culture, leadership, and organizations: The GLOBE study of 62 societies, Thousand Oaks, CA: Sage.

Jago, A.G. (1978): Configural cue utilization in implicit models of leader behavior, in: Organizational Behavior and Human Performance, 22, 3, 474-496.

Jago, A.G./Vroom, V.H. (1978): Predicting leader behavior from a measure of behavioral intent, in: Academy of Management Journal, 21, 4, 715-721.

Janis, I.L./Mann, L. (1977): Decision-making: A psychological analysis of conflict, choice, and commitment, New York: Free Press.

Judge, T.A./Piccolo, R.F./llies, R. (2004): The forgotten ones? The validity of consideration and initiating structure in leadership research, in: Journal of Applied Psychology, 89, $1,36-51$. 
Kark, R./van Dijk, D. (2007): Motivation to lead, motivation to follow: The role of selfregulatory focus in leadership processes, in: Academy of Management Review, 32, 2, 500-528.

Kost, M. (1994): Analyse der Industrieprivatisierung in Polen, Ungarn und der CSFR, Frankfurt a. Main: Peter Lang.

Lavigne, M. (1995):The economics of transition: From socialist economy to market economy, Basingstoke: MacMillan.

Lewin, K. (1935): Environmental factors in child behavior and development, in: Lewin, K. (ed.): A dynamic theory of personality, selected papers, New York: MacGraw-Hill, 66-113.

Lewin, K. (1958): Group discussion and social change, in: Maccoby, E.E./Newcomb, T.M./Hartley, E.L. (eds.): Readings in Social Psychology, New York: Holt, Rinehart and Winston, 197-211.

Lewin, K./Lippitt, R./White, R.K. (1939): Patterns of aggressive behavior in experimentally created social climates, in: Journal of Social Psychology, 10, 271-301.

Likert, R. (1961): New patterns of management, New York: McGraw-Hill.

Locke, E.A./Latham, G.P. (1990): Work motivation: The high performance cycle, in: Kleinbeck, U./Quast, H./Thierry, H./Häcker, H. (eds.): Work motivation, Hillsdale, NJ: Lawrence Erlbaum, 3-25.

Maczynski, J. (2001): The cultural impact on the leadership style of Polish managers, in: Polish Journal of Applied Psychology, 1, 1, 107-132.

Maier, N.R.F. (1955): Psychology in industry. $2^{\text {nd }}$ ed., Boston: Houghton Mifflin.

Maly, M. (2000): The management strategies of Czech companies in Transition, in: International Journal of Manufacturing Technology and Management, 1, 4/5, 405-411.

Marrow, A.J. (1977): Kurt Lewin, Leben und Werk, Stuttgart: Klett-Kotta.

McClelland, D.C. (1985): Human motivation, Glenview: Scott Forseman.

McClelland, D.C./Boytzis, R.E. (1982): Leadership motive pattern and long-term success in management, in: Journal of Applied Psychology, 67, 6, 737-743.

McClelland, D.C./Winter, D.G. (1969): Motivating economic achievement, New York: Free Press.

Meyer, H. (1982): Nocheinmal und zum letzen Mal: Was mißt der LPC Fiedlers?, in: Die Betriebswirtschaft, 42, 3, 427-439.

Miller, D./Friesen, P.H. (1984): Organizations, a quantum view, Englewood Cliffs, NJ: Prentice-Hall.

Miller, D./Friesen, P. (1980): Archetypes of organizational transition, in: Administrative Science Quarterly, 25, 2, 268-299.

Miller, G.A. (1956): The magical number seven, plus minus two: Some limits on our capacity for processing information, in: The Psychological Review, 63, 2, 81-97.

Miller, K.I./Monge, P.R. (1986): Participation, satisfaction, and productivity: A meta-analytic review, in: Academy of Management Journal, 29, 4, 727-753. 
Miner, J.B. (1984): The validity and usefulness of theories in an emerging organizational science, in: Academy of Management Review, 4, 2, 394-306.

Mirvis, P. (2008): Executive development through consciousness-raising experiences, in: Academy of Management Learning and Education, 7, 2, 173-188.

Moss, F.A. (1931): Preliminary report of a study of social intelligence, in: Public Personnel Studies, 9, 2-9.

North, D.C. (1990): Institutions, institutional change and economic performance, Cambridge: Cambridge University Press.

North, D.C. (1996): Institutions, organizations and market competition, Working Paper, EconWPA - Economic History, Nr. 9612005, URL: http://129.3.20.41/eps/eh/papers/9612/9612005.pdf.

Peters, L.H./Hartke, D.D./Pohlmann, J.T. (1985): Fiedler's contingency theory of leadership: An application of the meta-analysis procedures of Schmidt and Hunter, in: Psychological Bulletin, 97, 2, 274-285.

Pfeffer, J. (1977): The ambiguity of leadership, in: Academy of Management Review, 2, 1, 104-112.

Polany, M. (1976): Tacit knowing, in: Marx, M.H./Goodson, F.E. (eds.): Theories in contemporary psychology, 2 ed., New York: MacMillan, 330-344.

Reber, G. (1995): Führung: Bewegt sie oder wird sie bewegt? Antworten auf die Frage auf der Grundlage der Evaluierung von Wirkungen von Führungstrainings, in: Wunderer, R. (ed.): Betriebswirtschaftslehre als Management- und Führungslehre, 3 ed., Stuttgart: Schäffer-Poeschel, 395-415.

Reber, G. (1996): The development of a descriptive leadership model, in: Suominen, A. (ed.): Johtaminen Murroksessa (Management in Transition), Turku: Publications of the Turku School of Economics and Business Administration, 137-162.

Reber, G./Auer-Rizzi, W. (2003): The leadership behaviour of managers in Austria, the Czech Republic and Poland: An intercultural comparison based on the Vroom-Yetton model of leadership and decision making, in: Stüting, H.-J./Dorow, W./Claassen, F./Blazejewski, S. (eds.): Change management in transition economies: Integrating corporate strategy, structure and culture, New York: Palgrave Macmillan, 203-221.

Reber, G./Auer-Rizzi, W./Maly, M. (2004): The behaviour of managers in Austria and the Czech Republic: An intercultural comparison based on the Vroom/Yetton model of leadership and decision making, in: Journal of East European Management Studies, 9, 4, 411-429.

Reber, G./Jago, A.G. (1997): Festgemauert in der Erde... Eine Studie zur Veränderung oder Stabilität des Führungsverhaltens von Managern in Deutschland, Frankreich, Österreich, Polen, Tschechien und der Schweiz zwischen 1989 und 1996, in: Klimecki, R./Remer, A. (eds.): Personal als Strategie: Mit flexiblen und lernbereiten Human-Ressourcen Kernkompetenzen aufbauen, Bern: Haupt, 158-184.

Reber, G./Jago, A.G./Auer-Rizzi, W./Szabo, E. (2000): Führungsstile in sieben Ländern Europas - Ein interkultureller Vergleich, in: Regnet, E./Hofmann, L.M. (eds.): Personalmanagement in Europa, Göttingen: Verlag für Angewandte Psychologie, 154173. 
Reber, G./Jago, A.G./Böhnisch, W. (1993): Interkulturelle Unterschiede im Führungsverhalten, in: Haller, M./Bleicher, K./Brauchlin, E./Pleitner, H.-J./Wunderer, R./Zünd, A. (eds.): Globalisierung der Wirtschaft: Einwirkungen auf die Betriebswirtschaftslehre, Bern: Haupt, 217-241.

Reber, G./Jago, A.G./Maly, M. (2002): Leadership styles of managers in the Czech Republic: Changes over time (1991-2001) and cross-cultural comparisons with two other countries, Linz: Institute for International Management Studies, Johannes Kepler University Linz.

Roethlisberger, F.J./Dickson, W.J. (1939): Management and the worker, Cambridge, MA: Harvard University Press.

Rost, K./Osterloh, M. (2010): Opening the black box of upper echelons: Expertise and gender as drivers of poor information processing during the financial crisis, in: Corporate Governance - An International Review, 18, 3, 212-233.

Salancik, G.R./Pfeffer, J. (1977): Constraints on administrator discretion: The limited influence of mayors on city budgets, in: Urban Affairs Quarterly, 12, 4, 475-498.

Schreyögg, G./Sydow, J. (2011): Organizational path dependence: A process view, in: Organization Studies, 32, 3, 321-335.

Simon, H.A. (1960): The new science of management-decision, New York: Harper.

Singh, J.V. (1990): Organizational evolution, Newbury Park: Sage.

Sternberg, R.J./Vroom, V.H. (2002): The person versus the situation in leadership, in: The Leadership Quarterly, 13, 3, 301-323.

Stogdill, R.M. (1950): Leadership, membership, and organization, in: Psychological Bulletin, $47,1,1-14$.

Szabo, E./Jarmuz, S./Maczynski, J./Reber, G. (1997): Autocratic Polish versus participative Austrian leaders: More than a cliché?, in: Polish Psychological Bulletin, 28, 3, 279291.

Szabo, E./Reber, G./Weibler, J./Brodbeck, F./Wunderer, R. (2001): Values and behavior orientation in leadership studies: Reflections based on findings in three Germanspeaking countries, in: Leadership Quarterly, 12, 2, 219-244.

Tannenbaum, R./Schmidt, W.H. (1958): How to choose a leadership pattern, in: Harvard Business Review, 36, 2, 95-101.

Taras, V./Rowney, J./Steel, P. (2009): Half a century of measuring culture: Review of approaches, challenges, and limitations based on the analysis of 121 instruments for quantifying culture, in: Journal of International Management, 15, 4, 357-373.

Tjosvold, D./Wedley, W.C./Field, R.H.G. (1986): Constructive controversy, the Vroom/Yetton model, and managerial decision making, in: Journal of Occupational Behavior, 7, 2, 125-138.

Vroom, V.H. (1970): Industrial social psychology, in: Lindsey, G./Aronson, E. (eds.): Handbook of social psychology, Vol. I, Reading, MA: Addison-Wesley, 190-268.

Vroom V.H. (1993): Two decades of research on participation: Beyond buzz words and management fads, in: Yale Management, Spring 1993, 5, 22-32. 
Vroom, V.H. (2000): Leadership and the decision-making process, in: Organizatioal Dynamics, 28, 4, 82-94.

Vroom, V.H. (2003): Educating managers for decision making and leadership, in: Management Decision, 41, 10, 968-978.

Vroom, V.H./Jago, A.G. (1974): Decision making as a social process: Normative and descriptive models of leader behavior, in: Decision Science, 5, 4, 743-769.

Vroom, V.H./Jago, A.G. (1978): On the validity of the Vroom/Yetton model, in: Journal of Applied Psychology, 63, 2, 151-162.

Vroom, V.H./Jago, A.G. (1988): The new leadership: Managing participation in organizations, Englewood Cliffs, NJ: Prentice Hall.

Vroom, V.H./Jago, A.G. (2007): The role of the situation in leadership, in: American Psychologist, 62, 1, 17-24.

Vroom, V.H./Yetton, P.W. (1973): Leadership and decision-making, Pittsburgh: University of Pittsburgh Press.

Wagner, R.K./Sternberg, R.J. (1985): Practical intelligence in real-world pursuits: The role of tacit knowledge, in: Journal of Personality and Social Psychology, 49, 2, 436-458.

Zaccaro, S.J. (2007): Trait-based perspectives of leadership, in: American Psychologist, 61, 1, 6-16.

Zaccaro, S.J./Kemp, C./Bader, P. (2004): Leader traits and attributes, in: Antonakis, J./Cianciolo, A.T./Sternberg, R.J. (eds.): The nature of leadership, Thousand Oaks, CA: Sage, 101-124.

Zimmer, R.J. (1978): Validating the Vroom-Yetton normative model of leader behavior in field sales force management and measuring the training effects of TELOS on the leader behavior of district managers, Unpublished Dissertation, Virginia Polytechnic Institute and State University. 


\section{Appendix}

\section{Appendix 1: Decision strategies in the Vroom/Yetton model}

AI You solve the problem or make the decision yourself using the information available to you at the present time

AII You obtain any necessary information from subordinates, then decide on a solution to the problem yourself. You may or may not tell subordinates the purpose of your questions or give information about the problem or decision you are working on. The input provided by them is clearly in response to your request for specific information. They do not play a role in the definition of the problem or in generating or evaluating alternative solutions.

CI You share the problem with the relevant subordinates individually, getting their ideas and suggestions without bringing them together as a group. Then you make the decision. This decision may or may not reflect your subordinates` influence.

CII You share the problem with your subordinates in a group meeting. In this meeting you obtain their ideas and suggestions. Then you make the decision, which may or may not reflect your subordinates' influence.

GII You share the problem with your subordinates as a group. Together you generate and evaluate alternatives and attempt to reach agreement (consensus) on a solution. Your role is much like that of a chairperson, coordinating the discussion, keeping it focused on the problem and making sure that the critical issues are discussed. You can provide the group with information or ideas that you have, but you do not try to 'press' them to adopt 'your' solution and you are willing to accept and implement any solution, which has the support of the entire group.

\section{Appendix 2: Diagnostic questions (Situational characteristics) of the Vroom/Yetton model}

\section{Problem attributes}

A Does the problem possess a quality requirement?

$B \quad$ Do I have sufficient information to make a high quality decision?

C Is the problem structured?

$D \quad$ Is acceptance of decision by subordinates important for effective implementation?

$E$ If I were to make a decision by myself, is it reasonably certain that it would be accepted by my subordinates?

$F \quad$ Do subordinates share the organizational goals to be attained in solving this problem?

$G \quad$ Is conflict among subordinates over preferred solutions likely? 


\section{Appendix 3: Decision rules of the Vroom/Yetton model}

\section{Leader information rule $\mathrm{A}+\not \mathbf{P}$ :}

If the quality of the decision is important and the leader does not possess enough information or expertise to solve the problem alone, then $\mathrm{AI}$ is eliminated from the feasible set.

\section{Goal congruence rule $\mathrm{A}+\not \mathbf{F}$}

If the quality of the decision is important and subordinates are not likely to pursue the organization goals in their efforts to solve this problem, then GII is eliminated from the feasible set.

\section{Unstructured problem rule $\mathrm{A}+\not \mathfrak{B}+\not \subset$}

In situations in which the quality of the decision is important, if the leader lacks the necessary information or expertise to solve the problem alone, and if the problem is unstructured, the method of solving the problem should provide for information among subordinates likely to possess relevant information. Accordingly, AI, AII and CI, which provide no interaction among subordinates, are eliminated from the feasible set.

\section{Acceptance rule $\quad \mathrm{D}+\not 2$}

If the acceptance of the decision by subordinates is important for effective implementation and if it is not reasonably certain that an autocratic decision will be accepted, AI and AII are eliminated from the feasible set.

\section{Conflict rule $\quad \mathrm{D}+\not \notin+\mathrm{G}$}

If the acceptance of the decision is important, an autocratic decision is not reasonably certain to be accepted and disagreement among subordinates over possible solutions is likely, the methods used in solving the problem should enable those in disagreement to resolve their differences with full knowledge of the problem. Accordingly, under these conditions, AI, AII and CI, which permit no interaction among subordinates and therefore provide no opportunity for those in conflict to resolve their differences, are eliminated from the feasible set. Their use runs the risk of leaving some of the subordinates with less than the needed commitment to the final decision.

\section{Fairness-rule $\not X+D+\not 2$}

If the quality of the decision is unimportant, but acceptance of the decision is important, and not reasonably certain to result from an autocratic decision, the decision process used must generate the needed acceptance. The decision process should permit the subordinates to interact with one another and negotiate among themselves over the method of resolving any differences with full responsibility on them for determining what is fair and equitable. Accordingly, under these circumstances, AI, AII, CI and CII are eliminated from the feasible set.

\section{Acceptance priority rule $\mathrm{D}+\not \ell+\mathrm{F}$}

If acceptance is important, not reasonably certain to result from an autocratic decision and if subordinates are motivated to pursue the organizational goals represented in the problem, then methods which provide equal partnership in the decision making process can generate far greater acceptance without risking decision quality. Accordingly, AI, AII, CI and CII are eliminated from the feasible set. 